\title{
First record of the fish genus Symphysanodon (Teleostei: Perciformes: Symphysanodontidae) from the western South Atlantic Ocean
}

\author{
PAULA N. CAMPOS,${ }^{1}$ ANA CRISTINA T. BONECKER,${ }^{1}$ MÁRCIA S. DE CASTRO,${ }^{1}$ \\ \& WILLIAM D. ANDERSON, JR. ${ }^{2}$ \\ ${ }^{1}$ Universidade Federal do Rio de Janeiro, Instituto de Biologia, Departamento de Zoologia. CCS, Bloco A, Ilha do Fundão. CEP \\ 21941-590. Rio de Janeiro, RJ, Brasil.E-mail: polinhacampos@yahoo.com.br \\ ${ }^{2}$ Grice Marine Biological Laboratory, College of Charleston, 205 Fort Johnson, Charleston, South Carolina 29412-9110, USA. \\ E-mail: andersonwd@cofc.edu
}

\begin{abstract}
Two larval Symphysanodon, collected off the coast of Rio de Janeiro, southern Brazil (at 22³2'50.0” S, 04004'09.0” $\mathrm{W}$ ), beyond the 1,000 $\mathrm{m}$ isobath, are the first specimens of the monotypic family Symphysanodontidae to be reported from the western South Atlantic Ocean. We are unable to assign the larvae to a described species and entertain the idea that the Brazilian material may represent an undescribed species.
\end{abstract}

Key words: larvae, Brazil, range extension

\section{Introduction}

The marine fish family Symphysanodontidae is represented by a single genus, Symphysanodon (Anderson and Springer, 2005). Adults are small to medium-sized, occurring in depths of about 80 to $700 \mathrm{~m}$, in the Atlantic, Pacific, and Indian oceans (Anderson and Springer, 2005). Anderson and Springer (2005) recognized 10 species in the genus-six previously described, three that they described, and an undescribed one known only from the stomach contents of a specimen of Latimeria chalumnae. Recently, two other new species have been described-one by Khalaf and Krupp (2008) from the Gulf of Aqaba (Red Sea), the other by Quéro et al. (2009) collected off Reunion Island in the southwest Indian Ocean. Three species of Symphysanodon are known from the Atlantic Ocean (S. berryi Anderson, 1970; S. mona Anderson and Springer, 2005; and S. octoactinus Anderson, 1970), but the family has not been reported previously from the Brazilian coast (Menezes et al., 2003; Anderson and Springer, 2005; Bonecker and Castro, 2006; Costa et al., 2007).

Anderson and Springer (2005), in their key to the species of Symphysanodon, relied almost entirely on meristic and morphometric characters. That key works well for adults and most juveniles, but is not very useful for larvae. Although larvae of Symphysanodon are relatively easy to identify to genus, because of their distinctive head spination, they are often difficult to identify to species (Anderson and Springer, 2005). Many specimens, including some from the Atlantic, were not identified to species by Anderson and Springer (2005), in their review, in most cases, because of their small size, being larvae or postlarvae.

There is little published information on the larvae of species of Symphysanodon. Johnson (1984) illustrated (figure 254A) a 5.1-mm SL larva of an unidentified species of the genus, Leis and Trnski (1989:228-231, figure 51; 2000:394-398, figure 100) described and illustrated larvae collected in the Pacific, and Konishi (1988) described and illustrated larvae (of 3.8 and $10.5 \mathrm{~mm}$ ) identified as S. katayamai, a Pacific species. In this work, we report the first larval specimens (indeed the first specimens of any size) of Symphysanodon known to have been collected off the Brazilian coast. 


\section{Material and methods}

The material reported herein was collected on 06 November 2001 with a plankton net towed obliquely from $1,000 \mathrm{~m}$ to the surface off the coast of Rio de Janeiro, southern Brazil, at 22³2'50.0"S, 04004'09.0'W, preserved in a borax-buffered solution of $4 \%$ formalin, and deposited in the larval fish collection of the Zooplankton and Ichthyoplankton Integrated Laboratory of the Federal University of Rio de Janeiro, Brazil (DZUFRJ). Measurements of the larvae (mainly following Leis and Carson-Ewart, 2000:12-13), were made using the software Image Pro-Plus. Explanations of measurements, other than those of Leis and CarsonEwart, are: lengths of dorsal- and anal-fin bases = greatest overall basal lengths of fins, length of caudal peduncle $=$ oblique distance between posterior end of anal-fin base and base of mid-caudal-fin ray, and depth of caudal peduncle $=$ least depth of peduncle.

\section{Description of the specimens}

Larvae (DZUFRJ 21382), in postflexion stage, measure 7.63 and $8.84 \mathrm{~mm}$ SL (standard length). Early postflexion specimen $(7.63 \mathrm{~mm})$ with oblique mouth (Figure 1A); late postflexion larva $(8.84 \mathrm{~mm})$ with mouth more horizontal (Figure 1B). Body laterally compressed, head large and deep, eye round. Myomeres 25. Dorsal fin rays VIII, 11; anal fin rays III, 7 (Figure 1B). Length of gut more than 50\% SL; other measurements are in Table 1. Very long, heavily serrated frontal (Figure 1C) and preopercular (Figure 1D) spines; several smaller serrated preopercular spines (anterior two antrorse); small spines on subopercle, opercle, and interopercle; series of spines in both postorbital and infraorbital regions; serrated ridge in pterotic region; cluster of small spines in lachrymal region. Larvae lightly pigmented, but with some melanophores present at bases of dorsal and anal fins and on caudal peduncle dorsally and ventrally (Figure 1B).

TABLE 1. Morphometric data on two postflexion larvae of Symphysanodon (DZUFRJ 21382) collected in the western South Atlantic Ocean. Standard lengths are in mm; other measurements, in percentages of standard length.

\begin{tabular}{lll}
\hline Character & Larva 1 & Larva 2 \\
\hline Standard length & 7.63 & 8.84 \\
Head, length & 30.7 & 29.4 \\
Head, width & 31.8 & 27.6 \\
Snout, length & 11.1 & 9.4 \\
Eye, diameter & 11.8 & 11.6 \\
Predorsal-fin length & 43.5 & 42.5 \\
Preanal length & 63.0 & 61.8 \\
Body, depth & 27.6 & 25.7 \\
Dorsal-fin base, length & 32.8 & 37.1 \\
Anal-fin base, length & 14.4 & 14.1 \\
Vent to anal fin length & 1.0 & 0.6 \\
Caudal peduncle, length & 21.0 & 23.3 \\
Caudal peduncle, depth & 13.6 & 13.7
\end{tabular}

\section{Identification of the specimens}

We are not aware of any descriptions of larvae of Atlantic Symphysanodon. As can be seen in Figure 1B, the count of dorsal-fin rays in the larvae collected off Brazil is VIII, 11. Leis and Trnski (1989:229; 2000:395) 
wrote that in Symphysanodon: "All dorsal-and anal-fin elements are present in early postflexion larvae by 6.8 $\mathrm{mm}$. The posterior-most spine of both fins forms first as a soft ray and then transforms into a spine between 7.7 and $15 \mathrm{~mm}$." Consequently, the definitive dorsal-fin ray count for the species represented by the Brazilian larvae is IX, 10-by far the most common count of dorsal-fin rays found in all species of Symphysanodon.

Although the morphometric data in Table 1 may be useful for future workers in the identification to species of the larvae reported herein, the only morphological information presently available that may be of value in identifying these larvae is the number of soft rays, seven, in the anal fin. Among the described Atlantic species, Symphysanodon octoactinus almost always has eight, rarely seven, anal soft rays, making it unlikely that the larvae are members of that species, whereas $S$. berryi and S. mona have seven anal soft rays.

Symphysanodon mona is known only from a single specimen collected off the west coast of Puerto Rico, but "S. berryi has a wide geographic range, viz.: western Atlantic from off North Carolina and Bermuda to northern South America (including the West Indies, Gulf of Mexico, and Caribbean Sea), central Atlantic (off Ascension Island), and eastern South Atlantic (from localities well north of the Island of St. Helena and west of the Island of Pagalu)" (Anderson and Springer, 2005:30). Although S. berryi has not been reported from off southern Brazil and the outflow of the Amazon River would appear to be a significant barrier to dispersal that far south, Joyeux et al. (2001:831) noted that "the low-level differentiation between Caribbean and Brazilian species/populations, as well as the presence of restricted populations of a few northern or southern species on the opposite side of the Amazon River, clearly indicate that this barrier to dispersion can be occasionally bridged." If our larvae are representatives of a described species, the most likely candidate is $S$. berryi. Because we have not been able to assign the larvae to species and in consideration of the great distance between the nearest known locality for S. berryi (off Saint Lucia in the Lesser Antilles, Anderson and Springer, 2005) and the collection site for the larvae, it seems fitting to examine the possibility that the larvae represent an undescribed species.

Support for the notion that our larvae represent an undescribed species (conceivably two undescribed ones) comes from an examination of the geographic ranges of other species of Symphysanodon. Two widely distributed species of the genus, S. maunaloae and $S$. berryi, have more restricted geographic ranges than previously thought. Anderson (2000:2440) gave the distribution of S. maunaloae as "from the eastern South Pacific (Sala y Gómez Ridge) and Hawaii to Indonesia (off Lombok) and the Kyushu-Palau Ridge." The Symphysanodon from the Sala y Gómez Ridge was described as a new species, S. parini, by Anderson and Springer (2005). Anderson (2003:1306) wrote that "2 specimens . . indistinguishable from this species $[S$. berryi], have been obtained off the Maldives, southwest of Sri Lanka in the Indian Ocean." The Symphysanodon from off the Maldives is now recognized as a distinct species, S. rhax Anderson and Springer, 2005. Anderson and Springer (2005:38) wrote: "We suspect that the insular central and eastern South Atlantic specimens of $S$. berryi, although just slightly differentiated morphologically (showing only minor morphometric differences) from Caribbean conspecifics, are probably well differentiated and represent one or two species distinct from S. berryi." So-rather than representing a population of S. berryi, it seems quite likely that the larvae collected off the Brazilian coast represent an undescribed species of Symphysanodon.

Additional support for the contention that the Brazilian larvae of Symphysanodon are members of an undescribed species is provided by recent studies of Atlantic Ophioblennius (Blenniidae) and Canthigaster (Tetraodontidae). Using data derived from a study of the mitochondrial DNA cytochrome b gene, Muss et al. (2001) found that populations of Ophioblennius from the eastern, central, and western Atlantic, previously considered a single species by Springer (1962) on the basis of morphology, may represent several species which they did not describe. Subsequently, Floeter et al. (2008) and Hastings and Springer (2009) recognized three species of Ophioblennius in the Atlantic Ocean, and C. C. Baldwin (in litt. to WDA, 19 May 2009) has found morphological distinctions among some of the other putative species of Muss et al. (2001), supporting the recognition of additional species in the Atlantic. Populations of Atlantic Canthigaster in the eastern, central, and western Atlantic, usually considered as a single species, have been found to make up a complex of at least six species (Moura and Castro, 2002). 

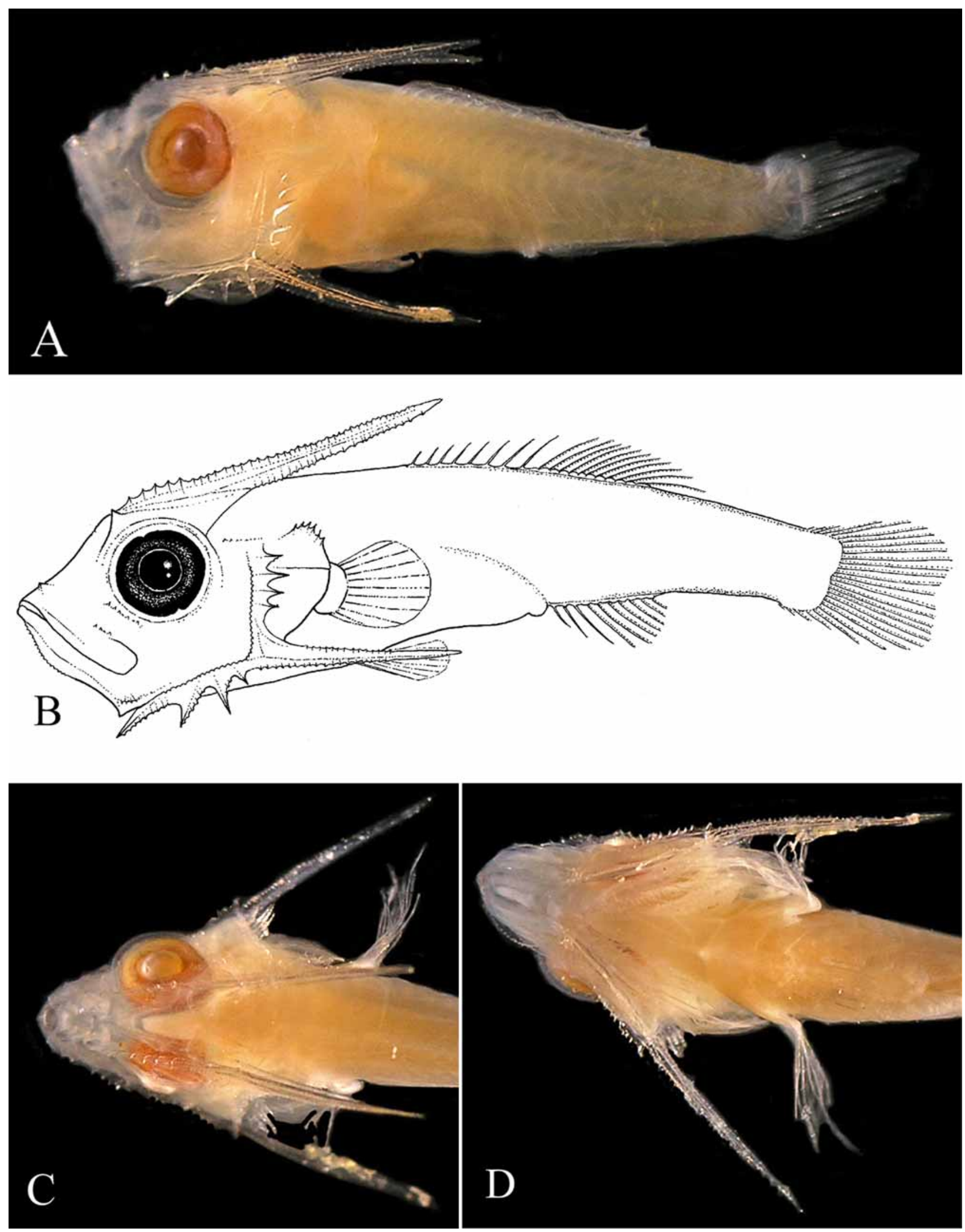

FIGURE 1. Postflexion larvae of Symphysanodon (DZUFRJ 21382) collected in the western South Atlantic Ocean. A. Specimen of $7.63 \mathrm{~mm} \mathrm{SL}$. B. Specimen of $8.84 \mathrm{~mm}$ SL. C. and D. Head spination in specimen of $8.84 \mathrm{~mm}$ SL: C. Dorsal view; D. Ventral view. 
An argument might be made that comparing speciation in reef or reef-associated fishes (such as Ophioblennius and Canthigaster) with speciation in deeper-dwelling genera (such as Symphysanodon ) is invalid because the factors promoting or limiting dispersal in the shallow- vs. deeper-water taxa are not the same, e. g., different directions of flow in shallow vs. deep oceanic currents. Adults of Symphysanodon have been taken over a wide depth range (50-705 m; 101-640 m for Atlantic species; Anderson and Springer, 2005), and, based on specimens in the collections of the Museum of Comparative Zoology, larvae of Symphysanodon have been collected over an even wider range (35-1190 m, with the majority of captures [36 of 51] made in less than $210 \mathrm{~m}$; data compiled from information received from Andrew Williston, in litt. to WDA, 25 August 2009). In view of the fact that the majority of the captures of larvae for which we have data were made in the epipelagic, it is reasonable to assume that, for the most part, the dispersal of Symphysanodon is influenced by the same current systems that affect reef or reef-associated fishes.

\section{Acknowledgments}

We thank the group at the Zooplankton and Ichthyoplankton Integrated Laboratory of the Federal University of Rio de Janeiro for assistance in field surveys and for sorting samples, Rafael Bendayan de Moura for providing Figure 1B, Pedro Freitas de Carvalho for the photographs in Figure 1, and Andrew Williston for furnishing data on the holdings of Symphysanodon in the ichthyological collections of the Museum of Comparative Zoology, Harvard University. We are grateful to CENPES/PETROBRAS for help in the field survey and for allowing publication of this study. Carole C. Baldwin, Sérgio Bonecker, Jeffrey M. Leis, and Victor G. Springer reviewed presubmission drafts of the manuscript. This is contribution number 347 of the Grice Marine Biological Laboratory, College of Charleston.

\section{References}

Anderson, W.D., Jr. (1970) Revision of the genus Symphysanodon (Pisces: Lutjanidae) with descriptions of four new species. Fishery Bulletin, 68(2), 325-346.

Anderson, W.D., Jr. (2000) Symphysanodontidae. In: Carpenter, K.E. \& Niem, V.H. (Eds.) FAO Species Identification Guide for Fishery Purposes. The Living Marine Resources of the Western Central Pacific. Vol. 4. Bony Fishes Part 2 (Mugilidae to Carangidae), Food and Agriculture Organization of the United Nations, Rome, pp. $2438-2441$. [Dated 1999, but actually published in 2000.]

Anderson, W.D., Jr. (2003) Symphysanodontidae. In: Carpenter, K.E. (Ed.) The Living Marine Resources of the Western Central Atlantic. Vol. 2. Bony Fishes Part 1 (Acipenseridae to Grammatidae). FAO Species Identification Guide for Fishery Purposes and American Society of Ichthyologists and Herpetologists Special Publication No. 5. Food and Agriculture Organization of the United Nations, Rome, pp. 1304-1307. [Dated 2002, but actually published in 2003.]

Anderson, W.D., Jr. \& Springer, V.G. (2005) Review of the perciform fish genus Symphysanodon Bleeker (Symphysanodontidae), with descriptions of three new species, S. mona, S. parini, and S. rhax. Zootaxa, 996, 1-44.

Bonecker, A.C.T. \& Castro, M.S. (2006) Atlas de Larvas de Peixes da Região Central da Zona Econômica Exclusiva Brasileira. Séries Livros No. 19. Museu Nacional, Rio de Janeiro, 216 pp.

Costa, P.A.S., Olavo, G. \& Martins, A.S. (2007) Biodiversidade da Fauna Marinha Profunda na Costa Central Brasileira. Séries Livros No. 24. Museu Nacional, Rio de Janeiro, 184 pp.

Floeter, S.R., Rocha, L.A., Robertson, D.R., Joyeux, J.C., Smith-Vaniz, W.F., Wirtz, P., Edwards, A.J., Barreiros, J.P., Ferreira, C.E.L., Gasparini, J.L., Brito, A., Falcón, J.M., Bowen, B.W. \& Bernardi, G. (2008) Atlantic reef fish biogeography and evolution. Journal of Biogeography, 35, 22-47.

Hastings, P.A. \& Springer, V. G. (2009) Recognizing diversity in blennioid fish nomenclature (Teleostei: Blennioidei). Zootaxa, 2120, 3-14.

Johnson, G.D. (1984) Percoidei: Development and relationships. In: Moser, H.G., Richards, W. J., Cohen, D.M., Fahay, M.P., Kendall, A.W., Jr., \& Richardson, S. L. (Eds.) Ontogeny and Systematics of Fishes. American Society of Ichthyologists and Herpetologists, Special Publication Number 1. Allen Press, Lawrence, Kansas, pp. 464-498. 
Joyeux, J.-C., Floeter, S R., Ferreira, C.E.L. \& Gasparini, J.L. (2001) Biogeography of tropical reef fishes: The South Atlantic puzzle. Journal of Biogeography, 28, 831-841.

Khalaf, M.A. \& F. Krupp (2008) A new species of the genus Symphysanodon (Perciformes: Symphysanodontidae) from the Gulf of Aqaba, Red Sea. aqua, International Journal of Ichthyology, 14(2), 85-88.

Konishi, Y. (1988) Symphysanodontidae. In: Okiyama, M. (Ed.), An Atlas of the Early Stage Fishes in Japan. Tokai University Press, Tokyo, 421-423. [Text in Japanese.]

Leis, J.M. \& Carson-Ewart, B.M. (Eds.) (2000) The Larvae of Indo-Pacific Coastal Fishes: An Identification Guide to Marine Fish Larvae. Brill, Leiden, $\mathrm{xx}+850 \mathrm{pp}$.

Leis, J.M. \& Trnski, T. (1989) The Larvae of Indo-Pacific Shorefishes. University of Hawaii Press, Honolulu, xii +371 pp.

Leis, J. M. \& Trnski, T. (2000) Symphysanodontidae. In: Leis, J. M. \& Carson-Ewart , B. M. (Eds.), The Larvae of IndoPacific Coastal Fishes: An Identification Guide to Marine Fish Larvae. Brill, Leiden, pp. 394-398.

Menezes, N.A., Buckup, P.A., Figueiredo, J.L. \& Moura, R.L. (2003) Catálogo das espécies de peixes marinhos do Brasil. Museu de Zoologia da Universidade de São Paulo, São Paulo, 160 pp.

Moura, R.L. \& Castro, R.M.C. (2002) Revision of Atlantic sharpnose pufferfishes (Tetraodontiformes: Tetraodontidae: Canthigaster), with description of three new species. Proceedings of the Biological Society of Washington, 115(1), 32-50.

Muss, A., Robertson, D.R., Stepien, C.A., Wirtz, P. \& Bowen, B.W. (2001) Phylogeography of Ophioblennius: The role of ocean currents and geography in reef fish evolution. Evolution, 55(3), 561-572.

Quéro, J.-C., Spitz, J. \& Vayne, J.-J. (2009) Symphysanodon pitondelafournaisei: Une nouvelle espèce de Symphysanodontidae (Perciformes) de l'île de La Réunion (France, ocean Indien). Cybium, 33(1), 73-77.

Springer, V.G. (1962) A review of the blenniid fishes of the genus Ophioblennius Gill. Copeia, 1962(2), $426-433$. 